\title{
Health in school: stress, individual responsibility and democratic politics
}

\author{
Claes Malmberg ${ }^{1} \cdot$ Anders Urbas $^{1}$
}

Received: 19 October 2017 / Accepted: 25 June 2018 / Published online: 22 August 2018

(c) The Author(s) 2018

\begin{abstract}
According to previous research, in contemporary western societies health is seen as an increasingly non-political issue. Rather than being at the centre of collective decisionmaking and democratic politics, health is regarded as resting on individual responsibility. In this study we focus on, and explore an important and challenging socio-scientific issue through the concepts of politicization and the depoliticization. We address the question of health education in schools as well as the question of citizenship and democracy, which adds to research on scientific literacy and socio-scientific issues. The study consists of two parts: firstly, we analyse whether health-more precisely stress - is portrayed as a political or non-political issue in textbooks for secondary school; secondly, and informed by the results from our analysis, we dissect and problematise what kind of citizenship that is constructed in textbooks. From a theoretical framework of politics, the article explores how citizenship emerges. Our findings show that health, and more precisely stress, is depoliticized in the textbooks. Firstly, stress is regarded as an individual-not public or governmental-concern. Secondly, stress is depoliticized in a more rigorous manner by making its political dimensions invisible. A consequence is a displacement of stress, e.g., in school, from the democratic arena to the individual citizen. As an implication we recommend an education that emphasize a political and democratic perspective on health as a complement to the individual perspective.
\end{abstract}

Keywords Secondary School $\cdot$ Health education $\cdot$ Socio-scientific issues $\cdot$ Stress $\cdot$ Politics

This study assumes that health, in contemporary western societies, is seen as an individual rather than a societal and/or political responsibility. Health, along with issues such as energy, sustainable development and education, is in today's political rationality characterized by depoliticization and responsibilization (e.g. Hillbur, Ideland and Malmberg 2016). During the last decades, what citizens collectively seek through political action has become less important than what the individual, as a customer, demands (Nordgren 2003, 2008).

Lead Editor: Matthew Weinstein.

Claes Malmberg

claes.malmberg@hh.se

1 Halmstad University, Halmstad, Sweden 
Reforms based on New Public Management and other neoliberal ideas have in many ways transformed the idea of citizenship and democracy (Aberbach and Christensen 2005).

The depoliticization of health is reflected in changes on both societal and individual levels. In contemporary western societies, the individual citizen is presumed to be active and take responsibility in a wide range of issues, such as within primary health care (e.g., Urbas, Mineur, Arvidsson and Tideman 2015) and education (e.g., Dovemark 2017). Matters of diet and exercise are also highly individualized. Carl Cederström and André Spicer (2015) described how contemporary diets require micro-regulation and self-surveillance such as regulated tables and prescriptions on what and when to eat. Self-surveillance functions as a governing technique inside the political rationality of what Peter Miller and Nicolas Rose (2008) called 'advanced liberal democracies', in which the power operates through the individual's 'free will' rather than against it. Already in 1980 Robert Crawford (1980) reflected on this rationality through the term 'healthism'. Healthism solicits the individual and locates the determinants of health as well as the solutions to health problems at the level of the individual.

The problem with healthism, as well as with other perspectives that are characterized by an individualization of health, is that it overlooks and obscures the social, economic and political determinants of and solutions to health problems (Crawford 1980). Research has shown that health and the distribution of health among nations and within nations are largely determined by things other than the choices made by the individual. In many ways, health is determined by the social and economic structure within and among populations (Wilkinson and Marmot 2003). Statistics show that the social gradient in health is a remarkably widespread phenomenon that runs through whole of society. This means that people with lower socioeconomic standard have worse health compared to those with better socioeconomic standard. Important to notice is that this does not only concern people in poverty. The social gradient is present in every level of the socioeconomic hierarchy which means that middle-class people generally have worse health than upper-class people. According Marmot (2011) this knowledge implies that we need to focus on the social determinants of health such inequalities that are reproduced by the circumstances in which people live and work.

The knowledge that the level and distribution of health among people depends on social, economic and political factors is important in two ways. Firstly, it contradicts the rationality of healthism, the view that situates health at the level of the individual, making the individual, on his or her own, responsible for his or her health. Secondly, it highlights the political dimension of health and redirects attention from the individual to the societal and political sphere. This has important implications, especially when it comes to questions of health-education in relation to citizenship and democracy. The role of education in the development of citizenship is widely recognized (Biesta 2003, 2008), and has been continuously scrutinized by scholars from different academic disciplines (e.g. Ekman 2007; Carlbaum 2012: Normark 2015; Sandahl 2015). The Swedish Education Act (SFS 2010:800) stipulates that the aim of education within the school system is to develop students into active, creative, competent and responsible individuals and citizens (Chapter 1, Sect. 4).

The question then is what kind of citizenship and democracy that is constructed by the educational system. This connects to the concept scientific literacy (Roberts 2011) which encompasses the development of citizenship characterized by a competence to consider and discuss complex socio-scientific issues (Ekborg, Ideland, Malmberg 2009), such as health. This study illuminates and analysis key features of contemporaneity, such as individuality and responsibility that are represented in science education (e.g. Martins 2017). 
The clash between responsibilization of health - as in healthism-and the social determinants of health-represented by Michael Marmot (2011) and Richard Wilkinson and Kate Pickett (2011) — is a paradox that needs to be highlighted and discussed. The paradox is to us a driving force behind this study and what motivates our aim. This article addresses health education, citizenship and democracy. We connect health education to a wider perspective through the question of how health education can be understood from a societal, cultural and political perspective. We follow WHOs' definition on health as a state of complete physical, mental and social well-being and not merely the absence of disease or infirmity. Our focus is on stress and how it is portrayed (as political or non-political) in textbooks, and its implications for citizenship and democracy. The stress approach emphasises subjective experiences and emotions that affect biology and, hence, physical and mental illness. Stress is strongly related to other health problems. Psychological experiences have profound effects on the body's system.

The aim of this article is threefold. Firstly, we analyse how stress and its causes and solutions are portrayed in textbooks. The question we answer is: "Is stress portrayed as a political or non-political issue in secondary school textbooks?" Secondly, and informed by the result, we discuss and problematize what kind of citizenship and democracy that thereby is constructed in the textbooks. Thirdly, we comment on the implications for future health education and the role the educational system should have when it comes to citizenship and democracy.

The interest of this study is not to analyse macro societal forces. Rather, we are interested in using the forthcoming theoretical canvas to problematize politicization and depoliticization and interrelations and contradictions vis-à-vis health education in school, not at least as a part of citizenship education. The educational system has an important role in creating citizens that can take part in democracy.

\section{Politics, citizenship and democracy}

\section{Politics, politicization and depoliticization}

In order to analyse how health (that is, stress) is described in Swedish textbooks, we need a conception of politics insofar that politics is closely related to citizenship and is a prerequisite for democracy. One key problem at the outset is that politics-as well as important concepts such as citizenship and democracy - is an essentially contested concept that is widely discussed within the social sciences (e.g., Hay 2002).

In this study, we have chosen a concept of politics (and politicization-depoliticization) presented by Colin Hay in Why We Hate Politics (2007, cf. 2014). According to Hay, politics share four different features. These are used by Hay to construct a broad and inclusive conception of politics (Hay 2007, p. 65). Firstly, politics can only occur in situations when human beings can choose; that is, in situations of choice (Hay 2007, p. 65). Secondly, and closely related, politics can only occur when human beings can make a difference; that is, when humans have the capacity for agency. In other words, politics only exists in situations that human beings can influence (Hay 2007, p. 66). The opposite-that is, situations when human beings do not have the capacity for agency-are situations that are non-political, which means that "[f]atalism and resignation are the antithesis of politics" (Hay 2007, p. 67) and that "[p]olitics is a realm of contingency; fate, one of inevitability and necessity" (Hay 2007, p. 68). Thirdly, politics is closely related to deliberation, which happens when 
human beings talk about, scrutinize, debate, draw attention to and explore options related to an issue. Fourthly, politics is a social activity, which means that politics only occurs in situations when activities and choices directly or indirectly have consequences for other human beings. If a person takes a decision which only affect him or her it is not a political decision since it does not affect other people. A political decision always comprises social and collective consequences.

There are three important aspects that we need to highlight, which are related to the four features of politics outlined above. Firstly, the concept of politics is closely related to our understanding of political participation. One way to illustrate different types of political participation is through a distinction between governmental or formal political arenas and non-governmental/private political arenas, and to relate these to what motivates political participation (Table 1). Based on this Hay has constructed a fourfold typology of political participation (Hay 2007).

Type-1 political participation includes voting in elections, membership in political parties and communication with politicians. All types of actions that aim to expand the realm of formal politics, such as lobbying, are included in Type-2 political participation. The quintessence in this type of political participation consists of the struggle to transform issues form merely being publicly discussed to being a part of the formal political system, for example by making the issues subject to new legislation (Hay 2007).

Political participation of Type 3 is a response to formal politics, but is located within the non-governmental arena. For example, it includes actions such as demonstrations against new legislation. Type-4 political participation includes participation such as attempts to influence (private) corporate practice by boycotts or ethical consumption, as well as attempts to draw public attention to issues previously not discussed.

The second aspect is whether an issue is political or non-political. This depends on whether it fulfils the four features mentioned above: choice, capacity for human agency, deliberation and social activity. The third aspect concerns to what degree an issue is politicized or depoliticized. Hay put forward three different spheres of the political (The

Table 1 Types of political participation (developed from Hay 2007). The table relates locus of political participation with motives for political participation

\begin{tabular}{|c|c|c|}
\hline \multirow[t]{2}{*}{ Locus of political participation } & \multicolumn{2}{|l|}{ What motivates political participation } \\
\hline & $\begin{array}{l}\text { Response to formal/governmental } \\
\text { concerns }\end{array}$ & $\begin{array}{l}\text { Response to non-governmental } \\
\text { concerns }\end{array}$ \\
\hline Formal/governmental & $\begin{array}{l}\text { Type 1: Political participation is } \\
\text { motivated by governmental action } \\
\text { such as new legislation and it is } \\
\text { orientated towards the formal } \\
\text { political system }\end{array}$ & $\begin{array}{l}\text { Type 2: This type of political } \\
\text { participation is-as Type } 1- \\
\text { oriented towards the formal } \\
\text { political system but motivated by } \\
\text { issues that are situated outside the } \\
\text { formal political system }\end{array}$ \\
\hline Non-governmental & $\begin{array}{l}\text { Type } 3 \text { : This type of political par- } \\
\text { ticipation is a reaction to actions } \\
\text { taken by the formal political } \\
\text { system but it carried out outside } \\
\text { the formal political system }\end{array}$ & $\begin{array}{l}\text { Type 4: This type of political } \\
\text { participation takes place outside } \\
\text { of the formal political system. } \\
\text { It is motivated by concerns that } \\
\text { are located within the public (or } \\
\text { private) but non-governmental } \\
\text { sphere and oriented towards } \\
\text { non-governmental arenas such as } \\
\text { the public }\end{array}$ \\
\hline
\end{tabular}


Governmental sphere, The Public sphere, The Private sphere), and one non-political arena (The Realm of necessity). According to Hay, the question of politicization and depoliticization is interconnected between the different spheres and the realm of necessity (Fig. 1). It is important to note that each of these spheres, according to Hay (2007, p. 79), are seen to be politicized to a lesser extent than the preceding one. Having said this it is important to highlight that this doesn't mean that the private sphere is or should be seen as non-political. On the contrary, and in accordance with Susan M. Okin in "Justice Gender and the Family" (1989), we want to emphasize the importance of adopting a broad conception of politics such as 'politics as power', which means that the private (or domestic) sphere is political.

Issues may be politicized in three different ways. An issue becomes political when human beings start to discuss it and maybe change it through actions; that is, when it becomes "...the subject of deliberation, decision making and human agency where previously they were not" (Hay 2007, p. 81). This, politicization 1, is associated with issues belonging to the realm of fate and necessity being moved over to the private sphere and human influence. This may involve the process when religious taboos or cultural assumptions become questioned and are subsequently possible to alter via human activities.

An issue might be further politicized when it becomes discussed or debated in public, and not only within the private sphere (politicization 2). Examples of this are demonstrations and other public activates that aim to highlight issues previously strictly situated within the private sphere. The last step (politicization 3) is if an issue becomes part of the governmental sphere; for example, if it becomes regulated by laws.

However, the dominant trend in the political rationalities of recent decades has been on depoliticization. Depoliticization is the opposite of politicization and works in reverse. An issue can be depoliticized in three ways. Depoliticization 1is when an issue that has

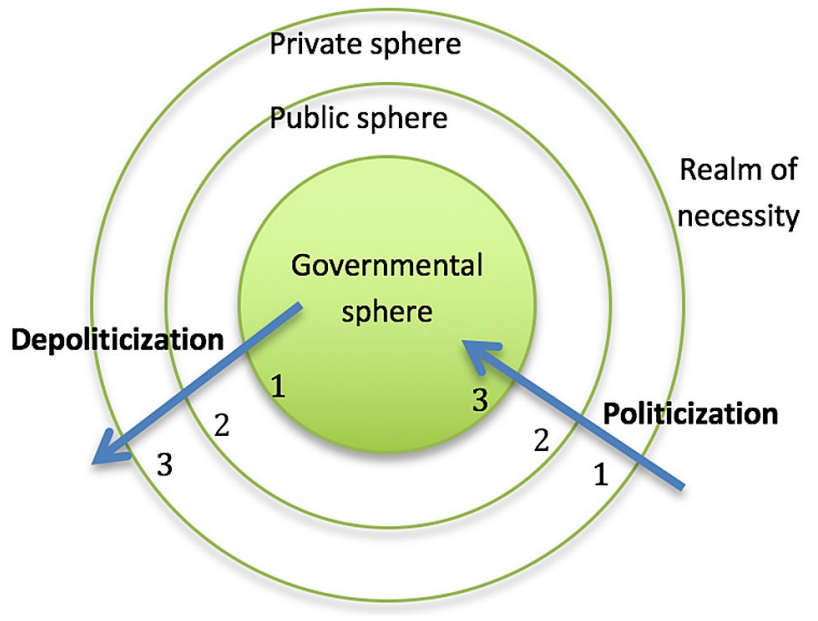

Fig. 1 Processes of politicization and depoliticization (developed from Hay 2007). Issues can be politicized in three different ways. Politicization (1) is a promotion from the realm of necessity to the private sphere; (2) is from the private sphere to the public sphere; and (3) is from the public to the governmental sphere. Depoliticization occurs correspondingly. Depoliticization (1) is a demotion from the governmental to the public sphere; (2) is from the public to the private sphere; and (3) from the private sphere to the realm of necessity 
been on the governmental arena (that is, discussed by politicians and perhaps the subject of legislation) is demoted to the public and non-governmental sphere. The way in which the responsibility for healthcare is handed over to companies is well described in researchthat is, to a sphere of distributed public governance (e.g. Hall 2012), along with how the public health system is increasingly using business rationalities. However, it is important to emphasize that this type of depoliticization does not mean that an issue becomes non-political. The issue is still political insofar as it fulfils the criteria (characteristics) for politics, but it is political to a lesser degree.

Depoliticization 2 consists of the process when an issue becomes a matter for the private sphere; for example, individual choice of healthy food. These issues are placed in the private sphere, becoming matters for individual choice and domestic deliberation (Hay 2007, p. 85).

Depoliticization 3 is when an issue is placed in the realm of necessity. It can be exemplified by 'a logic of no alternative' with respect to globalization or 'fate'. Simply stated, depoliticization 3 consists of issues being moved from the political spheres that are characterized by choice, capacity for agency and deliberation amongst humans to the realm of necessity and fate. Depoliticization of this type involves a disavowal of the capacity for deliberation, decision-making and human agency (Hay 2007, p. 86). There are a couple of important aspects that we need to emphasize with respect to this type of depoliticization: it does not only regard issues that are de facto non-changeable-on the contrary, this type of depoliticization can be made by human beings. The crucial point here is that the issues are viewed as non-changeable (Hay 2007, p. 87). Furthermore, this type of depoliticization can be achieved by less explicit and definite methods; for example, when societal issues for some reason are looked upon and perceived as non-changeable or, more precisely, when "... such matters cease to be cause for deliberation and/or collective choice" (Hay 2007, p. 87). The effect of this type of depoliticization, amongst others, is that the present is portrayed as the inevitable future, since the logic of no alternative has prevailed.

\section{Citizenship and democracy}

One key question is what we mean by citizenship and democracy. As with all concepts, citizenship and democracy are widely discussed and contested within the literature. We adopt an anti-essentialist view (Urbas 2009) on these concepts. At the same time, we are aware of the risk of using 'slippery' concepts that become loose. When a concept is articulated without any differentiation, it loses all meaning. To avoid 'concept stretching' we will briefly describe what we mean by citizenship and democracy. We argue, in line with Gert Biesta (2011), for a need to keep citizenship (and therefore citizen) education focused on politics and democracy. According to Biesta (2011) citizenship is characterized by both political engagement and collective decision-making that aims to transform individual issues into collective-political—concerns.

Our view of citizenship is connected to Hay's definition of politics that is distinguished by collective decision-making rather than by individual choice and responsibility. We do not deny the importance of things like individual autonomy, individual choice and responsibility. Rather, we highlight and emphasize the need for a stronger focus on citizenship and democracy.

Our view of politics, citizenship and democracy is characterized by the notion that politics is a prerequisite for democracy (as well as other forms of governing) and that democracy should be conceived as a process whereby citizens directly or indirectly-that is, 
through political institutions such as parliaments and political representatives-make decisions that govern the political association (e.g., Dahl 1989). As mentioned above, politics is distinguished by situations of choice, capacity for agency and social activity. Stated differently, the political exists in situations where there is conflict over different alternatives, and democracy is one of several ways of resolving conflicts (Mouffe 2005).

Viewing citizenship, politics and democracy in this way has two important implications. Firstly, and in accordance with Hay's view of politics (or Mouffe's view of the political), it clarifies that an elimination of key political components such as choice, capacity for agency or conflict and alternatives should be seen as depoliticization insofar as issues are then placed in the realm of necessity (even though they in fact are changeable by human intervention). Secondly, depoliticization of this sort (when issues are situated within the realm of necessity) is anti-democratic, and the process should be conceived as de-democratization. The reason for this is that politics, as defined above, is a necessity for democracy and other ways of governing an association, i.e., without politics there cannot be democracy.

Democracy is a contested concept, and there are many different models of democracy (Urbas and Trolle-Schultz Jensen 2015). In our understanding, democracy is a process whereby citizens govern over their association. Activities such as chatting online, boycotting certain products and debating different issues in school might be seen as political activities, but not as activities defining democracy. We follow Leif Lewin (2012) in his critic of the pragmatic view within the discipline of international political science: he highlighted its tendency to alter the meaning of democracy altogether by proposing new and different ways of understanding democracy. One can recognize the same tendency within citizen education, in which democracy can be understood as almost all activities performed by young people (Chou, Gagnon, Hartung and Pruitt 2017). In sum, we argue that democracy should be understood as an ongoing process where citizens directly or indirectly govern themselves, since the "democratic principle is government by the people" (Lewin 2012, p. $67)$.

\section{Method}

In this study we have analysed Swedish textbooks for secondary and upper-secondary school that explicitly address health issues. We are not trying to offer a comprehensive analysis of all teaching material. Rather, we used a selection of textbooks with representative examples to illustrate how stress is portrayed within them.

We started by examining the Swedish national curricula (Swedish National Agency for Education 2011) in order to find out which school subjects in the Swedish school system that are supposed to deal with health. We concluded that the following subjects are supposed to address health issues: biology; home and consumer studies; physical education and health; and science. Health is formally coupled with these subjects through the national curriculum and the core content for the subject. For biology and science, 'body and health' is a core content. For home and consumer studies, 'food, meals and health' is a core content, and for physical education and health, 'health and lifestyle' is a core content. This formal connection is reflected in the textbooks. We used the result from our analysis to select the textbooks used in this study. We made a selection of two textbooks from each subject for secondary and upper secondary school. The textbooks we chose are used in schools and predominant within each school subject. In the next step we read the textbooks 
Table 2 List of analysed textbooks

\begin{tabular}{llc}
\hline Book no. & Subject and school grade & References \\
\hline Book 1 & Biology, secondary school, years 7-9 & Andréasson (2011) \\
Book 2 & Biology, upper secondary school, years 10-12 & Henriksson (2013) \\
Book 3 & Science, upper secondary school, years 10-12 & Björndahl (2011) \\
Book 4 & Physical education and health, secondary school, years 7-9 & Gardestrand Bengts- \\
& & son and Gardestrand \\
& & (2015) \\
Book 5 & Physical education and health, upper secondary school, years 10-12 & Johansson (2012)
\end{tabular}

from a comprehensive perspective in order to obtain a primary but inclusive picture if and how stress is described. Our reading showed that five textbooks explicitly address stress (Table 2).

Our methodological approach in this article consists of a reconstruction and systematization of content that deals with stress and an analysis of the content based on the previously discussed theoretical canvas (concept of politics). Accordingly, we do not analyse why a certain view on stress is presented in the textbooks or which implications it will have on, for example, students in school. What we try to do is to discuss what kind of citizenship and democracy that is constructed within the textbooks, since the concepts are strongly interconnected to and dependent on politicization and depoliticization. Furthermore, our empirical material does not allow us to comment on how health (stress) has been handled from a historical perspective, or about the process of politicization or depoliticization, even though we sometimes use the word process. Lastly, the empirical data is collected from a limited Swedish context. Despite these limitations, we hope that this study will say something interesting concerning health education and inspire further research.

Finally, it is important to notice that stress as a physiological phenomenon always has been a part of human biological history. Despite this, the definition of stress-as short- or long-term bodily reactions to real or imagined stressors (Selye 1956; Marmot 2004; Björk 2011) — is quite recent. Stress, as a defined phenomenon, made it possible for researchers to understand different aspects and causes of stress. For example, according to Michael Marmot, modern research highlight and focus on five characteristics, all linked to the social hierarchy, when it comes to understanding the problem of stress: "control, predictability, degree of support, threat to status, and presence of outlets" (Marmot 2004: 114). In line with the core argument in Making up people (Hacking 2006) we can say that definition of stress has led to the identification of people with (and without) stress, institutions that deal with stress, knowledge production about stress and experts or professionals that create, judge and use the knowledge about stress.

\section{Stress in Swedish textbooks}

The textbooks for the subjects biology; home and consumer studies; physical education and health; and science deal extensively with health. However, only textbooks in biology and physical education and health and science explicitly describe stress, its causes, effects and ways to handle the problem of stress.

We use three categories to describe our results. The first category is physiological and psychological reactions to stress. For example, this includes hormonal production, bodily 
reactions and psychosocial factors. The next category deals with how the textbooks describe what causes stress. This goes beyond the biological markers, such as connections between cholesterol and blood pressure, and includes social determinants of stress. The determinants are described both on an individual or personal and on a societal or public level. The third category, ways to handle stress, illustrates how textbooks deal with solutions for stress.

\section{Physiological and psychological reactions to stress}

One key finding is that the textbooks describe stress as a biological phenomenon, and that reactions are described from a physiological perspective, similar for all mammals. However, stress is also described as a psychological reaction related to humans situated in a civilized world:

We have inherited a way to react to danger from our predecessors. Man was stressed when she met an enemy at the savannah. For her, it was important to quickly run away or stay and fight. The body's stress program started. People of today react in the same way, even if it's just the computer that is malfunctioning. However, we can either run away from or fight with the computer. But our body reacts in the same way as before. This creates a kind of stress that is not always good for us. (Book 1, p. 163)

According to the quote, stress is described as an inherited natural and biological response to threat, and the fight-or-flight response is seen as an adaptation from our predecessors' life on the savannah. The textbooks explain how the biological body react in acute stress. One book gives detailed (Book 2, p.254) information on how the hormones adrenaline and noradrenaline cause increased alertness, accelerated heart rate, increased blood pressure, increased blood flow to muscles, dilated airways, dilated pupils, increased sugar concentration and decreased activity in the digestive organs. These are described as natural reactions that help you to run or fight and use your body efficiently. It is said that, in a civilized world, these reactions will have negative consequences depending on the connection between body and mind.

Ongoing stress with low intensity causes long-term production of cortisol by the adrenal gland. This may cause serious effects. The metabolism will be affected which leads to powerlessness/.../the immune system is adversely affected and we will more often have infections, sleep disorders and depression. (Book 3, p. 243)

As we can see it is not only the fight-or-flight response that is discussed when it comes to reaction to stress. Ongoing long-term stress is also put forward as having a negative impact on the body and mind. Other examples of the body and mind connection are that one may be sad and worried if in pain, happy after a long walk, with a stomach ache if worried or high pulse when falling in love. Stress is said to be either short-term and explosive or having low intensity and long-term. The pressure one feels to meet requirements in school, as many students experience, exemplifies the latter form.

The descriptions in the textbooks in many ways place humans in the realm of necessity. It is humans' fate, as mammals, to react to stress.

\section{Social determinants of stress}

\section{Individual or personal level}

Good physical balance is described as something one has and something one needs for general wellbeing. Not taking care of the body will disturb this balance; for instance, if 
lacking sleep or exercise. Typically, it is expressed that human beings are built for movement and therefore must use the body to "make it [the body] feel good. We have to work out and exercise" (Book 5, p. 9). On an individual level, training and exercise are put forward as important determinants of one's health and wellbeing. The textbooks argue that people who exercise are not on sick leave very often. The best is if we become our own personal trainer (Book 5, p. 9). According to the textbooks, training has both social and psychological benefits: you protect yourself against stress, have fun and become happier, can stand psychological pressure better, and it may reduce the risk of depression and create better self confidence (Book 5, p. 14).

Stress is described as a matter of one's lifestyle. We are told that one's lifestyle is dependent on family habits, friends, advertisement and media. On the one hand, it is said that the individual person chooses his or her habits and way of living. On the other hand, stress is treated as something one is more or less sensitive to insofar as humans can train to become more stress tolerant, since you may react with stress when it is not really needed (Book 2, p. 254). One step is to be aware of one's stress reactions and of things causing stress. Long-time exposure to stress (for instance, when someone experiences that he or she cannot control his or her life) is severe. It may lead to the last level of stress, the fatigue syndrome. We are told that this may develop if a person is exposed to stress during a long time and is not listening to his or her body's warning signals (Book 2, p. 254). To avoid this, one needs to understand one's stress reactions (Book 4, p. 95).

Stress is typically placed within the private sphere. Besides, it is naturalized and described as something one has to adapt to and protect oneself from. It is something one has to learn to live with regardless of how sensitive the person is. There is, if use our theoretical canvas, a demotion from the private sphere to the realm of necessity.

\section{Societal or public level}

Stress is to a large extent described as caused by the societal or public and the governmental environments that surround the individual; that is, stress is according to the textbooks, in many ways caused by factors that are situated outside of the individual. There are four prominent causes of stress articulated in the textbooks.

Stress is, firstly, described as a part of western societies and is caused by modern digital technology, and more precisely by all the information that individuals constantly receive and have to process on daily basis. But stress is also caused by all the recommendations on how we should live and what we should do, as well as by the information that describes the future of society and the human impact on the environment. The amount and the content of the information that causes stress is described as closely related to other features of contemporary societies, such as the high pace and the rapid changes in the world (Book 3, p. 195 and 241).

Secondly, and related to the above, stress is described as caused by a key, organizational characteristic of western societies, namely all the choices that individuals are free to and must make in everyday life. Furthermore, the freedom and obligation to choose in different situations, such as deciding what to eat and drink, or whether or not to exercise, is connected with individual responsibility. Simply stated, the possibility and necessity of individual choice is followed by the question 'Did I make the right choice?', and is therefore a cause of stress (Book 3, p. 195).

Thirdly, stress is caused by different social and economic factors. Employment or the characteristics of work and the workplace, as well as unemployment, are used as examples 
of possible causes of stress. On the one hand, work is nowadays to a large degree characterized by high demands on the individual and a high pace, which might cause stress. Unemployment, on the other hand, is also a possible cause of stress (Book 5, p. 102; Book 2, p. 254).

Fourthly, stress is caused by the demands that are created by the educational system. There are different types of factors in the educational system (i.e., everyday school life) that cause stress. Even though the governmental aspects such as legislation are not explicitly stated, stress is caused by the regulation that governs the educational system. In other words, stress is caused by the demands that characterize characterise school-work; that is, demands to perform well, obtain good grades, etc. Furthermore and related to everyday school life, stress is caused by social aspects, such as having friends, performing well in different activities such as sports teams and not being excluded from friendship (Book 3, p. 242; Book 5, p. 102).

In short, according to the textbooks we have analysed, stress is caused by different external factors, namely:

1. All the information that needs to be processed

2. The freedom and obligation to choose in everyday life

3. Social and economic circumstances, such as unemployment

4. Demands in school, such as to perform well

Notably, the textbooks also highlight that we now live in an era that exposes us to things we are not adapted to, and which are caused by our way of living.

To summarise: so far we have analysed how textbooks describe physiological and psychological reactions to stress, as well as individual and social determinants of stress. We can notice that stress, from an individual point of view, emerges as an effect of bad habits, such as lack of sleep and exercise. It is also put forward that stress affects people in different ways. Therefore, individuals should 'listen' to their own bodies. However, stress is also explained through external factors caused by modern life, such as information flow and the freedom and obligation to choose. Other external factors mentioned include socioeconomic circumstances and demands from schoolwork. Causes are mainly situated on an individual, public and governmental level in comparison with Hay's spheres in Fig. 1. In the next section we analyse how textbooks deal with solutions; that is, ways of handling stress.

\section{Ways to handle stress}

The individual himself is usually the one who is best at perceiving his own stress and also the one who is best at counteract it. (Book 3, p. 244)

The quote above summarizes how the textbooks describe ways of handling and counteracting stress. Ways of handling stress are first and foremost described from an individual perspective, and sometimes as an antithesis to determinants to stress. For example, it can mean needing to calm down through relaxation when you are stressed. One book (Book 5, p. 104) offers a list of tips on what can be done to get rid of stress. In all books, activities as such mindfulness, yoga, tai chi, qui gong, meditation and massage are mentioned. Another book (Book 3, p. 244) describes how good sleep, physical contact (such as hugs or sex) or moments of peace and quiet will help the body's signal system to produce substances like dopamine, serotonin and endorphin that make us relaxed and contented. Two other 
activities mentioned - and that are said to be scientifically proven — that will help people to handle stress are visits in nature and listening to music.

Another method to reduce stress is to exercise. Exercise, in all forms, produces the substances mentioned above, and also means that you turn off your thoughts, become creative and come up with good ideas (Book 5, p. 104). The importance of an active lifestyle is underlined (Book 2, p. 254); "the purpose is to make you feel good, so you will thrive and succeed both in school and later in life".

Ways of handling stress are described on an individual level. However, one book (Book 3 , p. 242) touches upon how democracy creates possibilities to influence how to handle stress on a larger scale. According to the book, democracy is characterized by the opportunity to influence society through the right to vote. However, even if democracy is highlighted, the book emphasizes that individual choice and decisions, as well as one's own lifestyle, is the most important way to influence society (Book 3, p. 242). This is something we will elaborate on in the following section.

\section{Discussion}

The results from our analysis confirm previous research and what we referred to as healthism. Health, and more precisely stress, is depoliticized in the textbooks that we have studied. Firstly, stress is regarded as an individual — not public or governmental — concern. The textbooks do point out biological and individual as well as societal causes of stress, highlighting that stress might be caused by individual lifestyle choices and/or by societal and governmental factors such as demands in school. However, when it comes to handling stress, the societal and governmental aspects of stress disappear completely. Another way of putting it is that the problem of stress is not portrayed as something that should be discussed within the public sphere (politicization 2) and/or handled by the formal political (governmental) system (politicization 3). Rather, the perspective given to the student is that the only way to cope with stress is at the individual level. The individual should 'look inside' and find strategies such as yoga, exercise or walks in nature to handle the situation. In other words, stress and its causes are portrayed as non-political since there is no focus on such aspects as capacity for agency and change related to the societal and political level, and since the suggested activities only affect the individual, not other human beings.

Secondly, stress is depoliticized in a more rigorous manner than solely being viewed as an individual concern. The textbooks actually describe stress as a non-political issue by making its political dimensions invisible and by placing stress in what Hay (2007) calls 'the sphere of necessity'. This is not done explicitly by portraying stress and its causes as non-changeable; rather, it is done in a more subtle way. This type of depoliticization (3) is often elusive and characterised by making issues being viewed as predetermined and inevitable even though they in fact can be changed by human action.

As we have shown, the textbooks are characterized by an extreme one-sided focus on individual and personal responsibility. We are of course aware that the advices given are in accordance with research in health and well-being. However, the failure to highlight any societal and/or governmental factors - such as legislation on schooling or unemployment - as debatable and changeable by collective human action creates a world where factors outside of the individual are seen as natural and out of reach by human intervention. The perspective given in the textbooks implicates that individual adaptation, not collective public action, is the only way to handle stress. The only option 
given to the student is to find and use individual strategies to handle stress, not to discuss, scrutinize and by collective action try to change the cultural, societal, economic and political surrounding. In line with what Cederström and Spicer (2015) has written young citizens get a mindfulness session and other recommendations such as visits in nature or listening to music rather than an opportunity to influence decisions that affect their lives.

The depoliticization of stress in the textbooks becomes even more evident if we return to the four different types (Type 1-4) of political participation that Hay put forward. As we have described, political participation can be motivated by governmental and non-governmental concern and can be located within or outside of the formal political system. When it comes to the textbooks and the problem of stress, no political participation whatsoever is actualized, since key characteristics of the political (such as social activity) are lacking in the options presented to students. Ways of coping with stress do not include engaging in formal politics - for example by joining a political party and/or trying to change legislation (political participation types 1 and 2) or in non-governmental activates-for example, by organizing a public demonstration (political participation types 3 and 4) in order to change the causes of stress that are situated at the societal and governmental level. Rather, the view given in the textbooks is that the individual alone should place all of his or her efforts in changing himself or herself, thereby accepting and adapting to the current society.

As we have shown, one important consequence of the depoliticization of stress is that it undermines political participation of all four types. Furthermore, the depoliticization of stress downplays democracy. We have previously argued that politics-that is, when human beings are confronted with situations of choice and have a capacity for change that affects more people than the individual - is a prerequisite for democracy. Without politics there cannot be democracy. And this is the case in the textbooks. Firstly, the textbooks place stress within the sphere of necessity, or what Hay (2007) called 'a logic of no alternative' (p. 86), which depoliticizes stress, and as a consequence detaches stress from the democratic process. Secondly, the textbooks do point out that there is some room for action; that is, ways to handle stress. The problem here is that the recommendations given in the textbooks only put forward decisions taken by the individual that affect the individual him- or herself. The implication of this view is a depoliticization of stress and a displacement of stress from the democratic agenda.

As previously mentioned, our study confirms what we have referred to as healthism and other perspectives that focus on individual responsibility within a large range of fields. Therefore, we argue in line with Biesta (2011) that the main problem is that focusing on individual responsibility risks to depoliticize citizenship by seeing it as a individual phenomenon. In fact, it does not give young people the chance to grow as political actors who understand the opportunities as well as limitations of political action. We need to educate young citizens with knowledge about how to achieve real change, which often is a change of structures rather than an individual adaptation to current economic, political and social structures. This type of change often requires collective action.

Our analysis is limited to a selection of Swedish textbooks for secondary school. As such, we cannot comment on how stress is treated inside classrooms. Nonetheless, our study may have implications for health education. Issues about health typically turn to biology. However, recent research shows how important control and participation are for health. This leads to a different focus: to issues about what kind of lives we want to live, and in what kind of society we want to live them. If we want an educational system that promotes citizens that can take individual as well as politic and democratic responsibility, then health issues, as well as other important issues, must be discussed from 
different perspectives. More precisely, the individual perspective must be complemented by a political and democratic perspective on health.

Acknowledgement This article was made possible thanks to support from Halmstad University, School of Education, Humanities and Social Sciences.

Open Access This article is distributed under the terms of the Creative Commons Attribution 4.0 International License (http://creativecommons.org/licenses/by/4.0/), which permits unrestricted use, distribution, and reproduction in any medium, provided you give appropriate credit to the original author(s) and the source, provide a link to the Creative Commons license, and indicate if changes were made.

\section{References}

Aberbach, D. J., \& Christensen, T. (2005). Citizens and consumers. An NPM dilemma. Public Management Review. https://doi.org/10.1080/14719030500091319.

Andréasson, B. (2011). Biologi: för grundskolans år 7-9 [Biology for compulsary school, year 7-9]. Stockholm: Natur \& Kultur.

Biesta, G. (2003). Demokrati-ett problem för utbildning eller ett utbildningsproblem [Democracy-A problem for education or an educational problem]. Utbildning och demokrati, 12(1), 59-80.

Biesta, G. (2008). What kind of citizen? What kind of democracy? Citizenship education and the Scottish curriculum for excellence. Scottish Educational Review, 40(2), 38-52.

Biesta, G. (2011). Learning democracy in school and society: Education, lifelong learning, and the politics of citizenship. Rotterdam: Sense Publishers. https://doi.org/10.1007/978-94-6091-512-3.

Björk, M. (2011). Problemet utan namn? neuroser, stress och kön i Sverige från 1950 till 1980 [The problem without name? Neuros, stress and gender in Sweden from 1950 to 1980]. (Diss.). Uppsala: Uppsala University.

Björndahl, G. (2011). Frank gul: naturkunskap. 1 [ [Frank yellow: Science]. Stockholm: Liber.

Carlbaum, S. (2012). Blir du anställningsbar lille/a vän? Diskursiva konstruktioner av framtida medborgare i gymnasiereformer 1971-2011. [Are you employable little friend? Discursive constructions of future citizens in reforms for upper secondary school 1971-2011] (Diss). Umeå: Umeå University.

Cederström, C., \& Spicer, A. (2015). The wellness syndrome. Cambridge: Polity.

Chou, M., Gagnon, J.-P., Hartung, C., \& Pruitt, L. (2017). Young people, citizenship and political participation. Combating civic deficit?. London, New York: Rowman and Littlefield.

Commission for a Socially Sustainable Malmö (2013). Malmö's path towards a sustainable future. Health, welfare and justice. Downloaded 2017-09-21. http://malmo.se/download/18.1d68919c14 31f1e2a96c8e4/1491298331527/malmo\%CC\%88kommisionen_rapport_engelsk_web.pdf.

Crawford, R. (1980). Healthism and the medicalisation of everyday life. International Journal of Health Services, 10(3), 365-388. https://doi.org/10.2190/3H2H-3XJN-3KAY-G9NY.

Dahl, A. R. (1989). Democracy and its critics. New Haven and London: Yale University Press.

Dovemark, M. (2017). Utbildning till salu-konkurrens, differentiering och varumärken [Education for sale-Competition, differentiation and brands]. Utbildning \& Demokrati, 26(1), 67-86.

Easton, D. (1965). A framework for political analysis. London: Prentince-Hall INC.

Ekborg, M., Ideland, M., \& Malmberg, C. (2009). Science for life: A conceptual framework for construction and analysis of socio-scientific cases. NorDiNa, 1, 35-46.

Ekman, T. (2007). Demokratisk kompetens. Om gymnasiet som demokratiskola [Democratic competence. About upper secondary school as a democracy school]. (Diss). Göteborg: Gothenburg University.

Fitzpatrick, K., \& Tinning, R. (2014). Concider the politics and practice of health education. In K. Fitzpatrick \& R. Tinning (Eds.), Health education: Critical perspectives (pp. 1-5). London: Routledge.

Gardestrand Bengtsson, M., \& Gardestrand, S. (2015). Idrott och hälsa. 7-9 [Physical education and health. 7-9]. Stockholm: Liber.

Hacking, I. (2006). Making up people. London Review of Books, 28(16), 23-26.

Hall, P. (2012). Managementbyråkrati: organisations politisk makt i svensk offentlig förvaltning [Management bureaucracy: Organizational political power in Swedish public administration]. Malmö: Liber.

Hay, C. (2002). Political analysis. A critical introduction. New York: Palgrave. https://doi.org/10.1007/9780-230-62911-0. 
Hay, C. (2007). Why we hate politics. Cambridge: Polity.

Hay, C. (2014). Depoliticisation as process, governance as practice: What did the 'first wave' get wrong and do we need a 'second wave' to put it right? Policy \& Politics, 42(2), 293-311. https://doi. org/10.1332/030557314X13959960668217.

Henriksson, A. (2013). Iris biologi. 2. Malmö: Gleerup.

Hillbur, P., Ideland, M., \& Malmberg, C. (2016). Response and responsibility: Fabrication of the eco-certified citizen in Swedish curricula, 1962-2011. Journal of Curriculum Studies, 48(3), 409-426. https:// doi.org/10.1080/00220272.2015.1126358.

Johansson, B. (2012). Idrott och hälsa [Physical education and health]. Stockholm: Liber.

Lasswell, H. (1936). Politics: Who, gets what, when, and how. Cleveland and New York: Meridian Books.

Lewin, L. (2012). Statsvetenskapens grunder [Fundamentals of political science]. Lund: Studentlitteratur.

Lundström, U. (2017). Att mäta det vi värderar eller värdera det vi kan mäta? Resultatindikatorer som grund för skolval [Measuring what we value or value what we can measure? Performance indicators as a basis for school elections]. Utbildning \& Demokrati, 26(1), 43-66.

Marmot, M. (2004). The status syndrome: How social standing affects our health and longevity. New York, NY: Holt Paperbacks.

Marmot, M. (2011). Introduction. In M. Marmot \& R. Wilkinson (Eds.), Social determinants of health (pp. 1-6). Oxford: Oxford University Press.

Martins, I. (2017). In which ways can (Science) education promote the well-beings of individuals, society and environments? In L. Bencze (Ed.), Science and technology education promoting wellbeing for individuals, societies and environments STEPWISE. Cham: Springer International Publishing. https:// doi.org/10.1007/978-3-319-55505-8_29.

Miller, P., \& Rose, N. S. (2008). Governing the present: Administering economic, social and personal life. Cambridge: Polity.

Mouffe, C. (2005). On the political. London: Routledge.

Nordgren, L. (2003). Från patient till kund. Intåget av marknadstänkande i sjukvården och förskjutningen av patientens position [From patient to customer. The inclusion of market thinking in the health care sector and the displacement of the patient's position]. (Diss). Lund: Lund Business Press.

Nordgren, L. (2008). The performativity of the service management discourse- "Value Creating Customers" in health care. Journal of Health Organization and Management, 22(5), 510-528.

Normark, J. (2015). Med en framtida demokrat som adressat. Föreställningar om framtid i svenska samhällskunskapsböcker 1992-2010 [With a future democrat as an addressee. Performances of the future in Swedish Social Sciences Books 1992-2010]. (Diss). Västerås: Mälardalen University.

Okin, S. M. (1989). Justice, gender, and the family. New York: Basic Books.

Popper, R. K. (1966a). The open society and it's enemies, Vol. 1: The spell of plato. London: Routledge.

Popper, R. K. (1966b). The open society and it's enemies, Vol 2: The high tide of prophecy: Hegel, Marx and the aftermath. London: Routledge.

Roberts, D. A. (2011). Competing visions of scientific literacy: The influence of a science curriculum policy image. In C. Linder, L. Ostman, D. A. Roberts, P. Wickman, G. Erickson, \& A. MacKinnon (Eds.), Promoting scientific literacy: Science education research in transaction (pp. 11-27). New York, NY: Routledge/Taylor and Francis Group.

Rose, N. (2000). Government and control. The British Journal of Criminology, 40(2), 321-339. https://doi. org/10.1093/bjc/40.2.321.

Rose, N., \& Miller, P. (1992). Political power beyond the state: Problematics of government. British Journal of Sociology, 43(2), 173-205. https://doi.org/10.2307/591464.

Rostila, M., \& Toivanen, S. (2012). Den orättvisa hälsan. Om socioekonomiska skillnader i hälsa och livslängd [The unfair health. About socioeconomic differences in health and lifespan]. Stockholm: Liber.

Sandahl, J. (2015). Medborgarbildning $i$ gymnasiet. Ämneskunnande och medborgarbildning $i$ gymnasieskolans samhälls- och historieundervisning [Citizenship education in high school. Subject knowledge and citizenship education in the upper secondary school's social and history education] (Diss). Stockholm: Stockholms University.

Selye, H. (1956). The stress of life. New York: McGraw-Hil.

Swedish Education Act 2018:800 (Skollagen 2010:800).

Urbas, A. (2009). Den svenska valforskningen Vetenskapande, demokrati och medborgerlig upplysning [The Swedish election studies Science Democracy and citizen enlightment]. Örebro Studies in Political Science 26. Örebro: Örebro University Press.

Urbas, A., Mineur, T., Arvidsson, J., \& Tideman, M. (2015). Valfrihetssystem inom primärvården och personer med intellektuell funktionsnedsättning-en kunskapsöversikt. [System of choice whithin primary care and people with intellectual disabilities-A knowledge overview] Nordisk Administrativt Tidsskrift. 2 (92). 
Urbas, A., \& Trolle-Schultz Jensen, J (2015). Vetenskap, politik och kommunikation [Science, Politics and Communication]. In Bengtsson, H. (ed.). Vinklade budskap-perspektiv på politisk kommunikation. [Angled message-Perspective on political communication]. Forskning i Halmstad 23, 33-46. Halmstad: Halmstad University Press.

Wilkinson, R., \& Marmot, M. (2003). The solid facts. Copenhagen: World Health Organization.

Wilkinson, R. G., \& Pickett, K. (2011). The spirit level: Why greater equality makes societies stronger. New York: Bloomsbury.

Zeidler, D. (2014). Socioscientific issues as a curriculum emphasis: Theory, research and practice. In N. G. Lederman \& S. K. Abell (Eds.), Handbook of research on science education (Vol. 2, pp. 697-726). New York, NY: Routledge.

Claes Malmberg is a professor in science education and Ph.D. in education. He is currently working at Halmstad University, Sweden. His research interests are on cultural and politcal perspectives on science education, health education and education for sustainable development.

Anders Urbas, Ph.D. in Political Science, is currently working at Halmstad University, Sweden. Anders research interests are focused on politics, democracy and citizenship. 